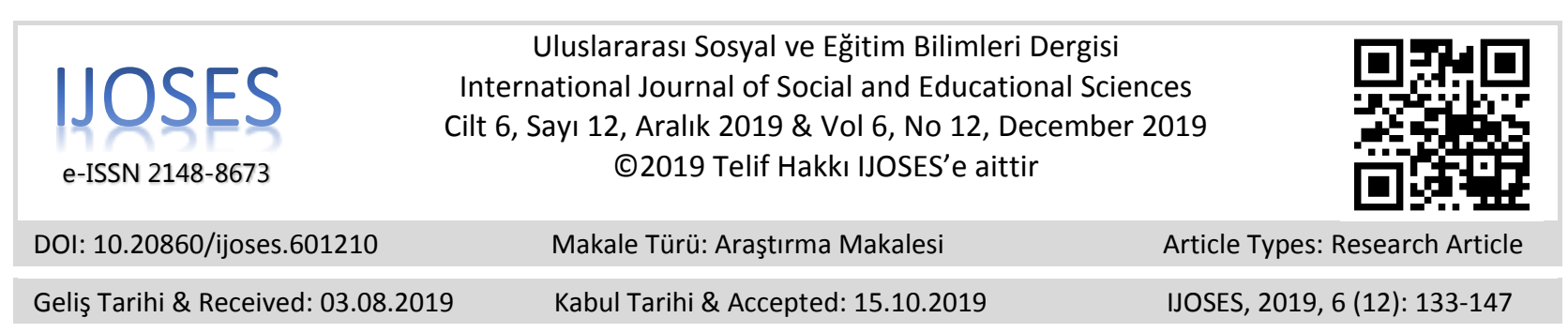

\title{
1960’lar Sonrası Kütüphanecilik Tarihimiz İçinde Bazı “Kütüphane Haftası” Afişlerinin Roland Barthes’in Göstergebilim Metodu Çerçevesinde Analizi
}

\author{
In Our History of Lıbrary after 1960s; Analysis of Some “Lıbrary Week” Posters in the Framework of Roland \\ Barthes's Semiotıcs Method
}

\section{Hüseyin Hilmi Aladağ $\breve{g}^{*}$}

Öz

Akademik camiamızda duyuru/tanıtım afişlerinin göstergebilimsel analizi konusunu ele alan araştırmaların “Türkiye'de kütüphane ve kütüphanecilik tarihi" bakımından mevcut araştırmalar dikkate alındığında yetersiz oluşu muhtemelen yöntemin bizde henüz yeni olmasından ve bu sahada henüz yeterince tatbik edilmemesinden kaynaklıdır. Devlet kurumları ya da özel kurumlar, topluma ve insanlara vermek istedikleri mesajları çeşitli araçlarla ulaştırabilmektedir. Bilhassa 20.yy içinde bu araçlardan biri de "tanıtım afişleri” olmuştur. Halen tesirini muhafaza eden tanıtım afişleri, toplumun kültürel ve sosyal yapısını aksettirmek bakımından mühim bir rol üstlenmektedir.

Göstergebilimsel analiz metoduyla yazılı ve görsel materyallerin hangi amaç/amaçlar için kullanıldığını, ne türden açık ve gizli mesajlar içerdiğini ve bu mesajların anlam katmanlarının deşifre edilmek ya da tefsir edilmek suretiyle niyetini (intentio) açık etmek mümkündür.

Bu makale kapsamında T.C Kültür ve Turizm Bakanlığı'na bağlı Kütüphaneler ve Yayımlar Genel Müdürlüğü web sayfasında yer alan Kütüphane Haftası tanıtım afişlerinden yedisi göstergebilim (semiyotik metot) açısından incelenmiştir. Bu bakımdan makalenin amacı "kütüphane haftası" duyuru/tanıtım afişlerinin semiyotik analiz yöntemi kullanılarak içeriğindeki verilmek istenen mesajların çözümlenmesidir. Kütüphaneler ve Yayımlar Genel Müdürlüğü web sayfasından seçilen toplam afiş sayısı yedidir. Araştırma kapsamında amaçlı örneklem tekniği kullanılmıştır. Göstergebilimsel çözümlemede ise Roland Barthes modelinden faydalanılmıştır.

Anahtar Kelimeler: Türk Kütüphanecilik Tarihi, Kütüphane Haftası, Tanıtım Afişleri, Göstergebilim

\begin{abstract}
Research on the semiotic analysis of announcements/publicity posters in our academic community is inadequate because the method is new in terms of "library and Library History in Turkey". State institutions or private institutions can convey the messages they want to give to society and people through various means. These tools was "promotional posters" especially in the 20 . century. Promotional posters, which still maintain their influence, play an important role in promoting the cultural and social structure of society.

It is possible to explain the purpose of the written and visual materials for which purpose/purposes are used by the method of semiotic analysis, what kind of clear and secret messages are used, and the intention of the meaning of these messages to be deciphered or interpreted.

In this article seven of The Library Week publicity posters on the web page of the Turkish Republic General Directorate of libraries and Publications of the Ministry of Culture and Tourism have been examined from semiotics. In this regard, the purpose of the article is to analyze the messages that are intended to be conveyed in the content by means of the semi-analytical method of announcement/advertisement posters. The total number of posters on the Web page of the General Directorate of libraries and Publications is 7. Purpose sampling was performed within the scope of the research. In semiological analysis, Roland Barthes's method was used.
\end{abstract}

Keywords: History of Turkish Library, Library Week, Publicity Posters, Semiotics.

* (Dr. Öğr. Üyesi); Osmaniye Korkut Ata Üniversitesi, Sosyal ve Beşeri Bilimler Fakültesi, Bilgi ve Belge Yönetimi Bölümü, hilmialadag@osmaniye.edu.tr ORCID: orcid.org/0000-0001-5317-5777

Kaynak Gösterme: Aladağ, H. H. (2019). 1960’lar Sonrası Kütüphanecilik Tarihimiz İçinde Bazı "Kütüphane Haftası” Afişlerinin Roland Barthes'in Göstergebilim Metodu Çerçevesinde Analizi. Uluslararası Sosyal ve Eğitim Bilimleri Dergisi, 6 (12), 133-147. DOI: 10.20860/ijoses.601210 


\section{Extended Summary}

Within the scope of this article, the Library Week presentation posters of the Ministry of Culture and Tourism General Directorate of Libraries and Publications are examined by semiology method. Banners prepared within the scope of Library Week were analyzed using Barthes' semiotic analysis method. The main aim of the research was to examine the posters of the library week by examining the banners with the semiotic analysis method and the messages that were intended to be given in the posters were examined. The total number of posters selected from the General Directorate of Libraries and Publications web site was seven and the sampling technique was used for the purpose of the research.

Banner, in general terms; It can be defined as the promotional media of various shapes and sizes located in the places where people can see in all living areas of the society and thus informing and guiding people. Poster design has changed according to almost every period. The reason for this is that the designers of the period have also exhibited works that are directly proportional to the perception of art and the view of people. (Akengin ve Mazlum, 2018, s. 1614).

Semiology is accepted as a useful technique with its applicability to almost any discipline. Semiotics is the process of review and interpretation of written and visual elements by considering certain criteria. In this interpretation process, cultural changes and social structure are considered. (Oruç ve Türkay, 2018, s. 313).

In semiotics analysis, because the main objective, meaning and meaning of the formation is to examine the structure of the examination object is expected to be a holistic and completed structure. The purpose and tools of this concept can be determined by means of semiotics considering that the object to be examined provides a meaning to the recipient in this context. (Kiran, 2004, s. 51).

It is the part of a regular indicator that appears invisible or, in other words, does not require interpretation in the middle. The answer requires a comment when creating a "upper language". The indicator is interpreted in the cultural information of the viewer. In other words, connotation can be shaped within the knowledge, experience and thoughts of the individuals who use that language. Each indicator necessarily contains a flame. It can be interpreted differently from culture to culture. (Er, 2012, s. 118).

In this research will try to answer the following questions in particular:

What is included in the sample group posters prepared within the framework of "Library Week" in terms of "plain meaning" and "side meaning"?

Posters prepared within the framework of the Library Week, which metaphor, metonym and myth concepts presented with?

As a result of the analyzes, metaphoric and metonymic narrative has been applied to the posters in order to construct a "semantic meaning" and "upper language". The posters were designed in parallel with the socio-political, socio-economic and socio-cultural events in the world at the macro level. Banners in the same sense; At the micro level, socio-political, socio-economic and socio-cultural events are designed in our country. With the semiotic analysis method, it is possible to determine which purposes the written and visual materials are used for. With this research, after revealing what kind of clear and implicit messages our library week posters are in our country, it is our main motivation to examine the meaning layers of these messages in order to make more qualified studies. 


\title{
Giriş
}

Devlet kurumları ya da özel kurumlar, topluma ve insanlara vermek istedikleri mesajları çeşitli araçlarla ulaştırabilmektedir. Bilhassa 20.yy içinde bu araçlardan biri de "tanıtım afişsleri”" olmuştur. Halen tesirini muhafaza eden tanıtım afişleri, toplumun kültürel ve sosyal yapısını aksettirmek bakımından mühim bir rol üstlenmektedir. Akademik camiamızda duyuru/tanıtım afişlerinin göstergebilimsel analizi konusunu ele alan araştırmalar genelde yöntemin bizde henüz muhtelif disiplinlere tatbikinin yeni olmasından dolayı yetersizdir. Özelde ise; ilgili literatür taranmış fakat “Türkiye'de kütüphane ve kütüphanecilik tarihi” bakımından göstergebilim yönteminin uygulandığ1 herhangi bir çalışmaya ulaşılamamıştır.

Bu makale kapsamında T.C Kültür ve Turizm Bakanlığı'na bağlı Kütüphaneler ve Yayımlar Genel Müdürlüğü web sayfasında yer alan Kütüphane Haftası tanıtım afişlerinden seçilenler göstergebilim bakımından incelenmiştir. Bu bakımdan makalenin amacı "kütüphane haftası" duyuru/tanıtım afişlerinin semiyolojik/semiyotik analiz yöntemi ile içerikte verilmiş ya da verilmek istenen mesajların çözümlenmesidir. Kütüphaneler ve Yayımlar Genel Müdürlüğü web sayfasından seçilen toplam afiş sayısı yedidir. Araştırma kapsamında amaçlı örneklem tekniği kullanılmıştır. Göstergebilimsel çözümlemede ise Roland Barthes modelinden faydalanılmıştır.

\section{Kütüphane Haftası}

Ülkemizde her yıl kutlanan Kütüphane Haftası ile ilgili olarak Kültür ve Turizm Bakanlığ1 Kütüphaneler ve Yayımlar Genel Müdürlüğü'nün internet sayfasında şu bilgilere ulaşılabilmektedir.

\begin{abstract}
Vatandaşların kütüphaneleri yakından tanımaları ve kütüphanelerden daha çok yararlanmalarını teşvik etmek amacı ile her yıl Mart ayının son Pazartesi günü başlayan hafta, ülkemizde Kütüphane Haftası olarak kutlanmaktadır. İlki 1964 yılında başlayan Kütüphane Haftası kutlama etkinliklerinde, yurt çapında kütüphane ve kütüphanecilik konularını ele alan konferanslar, sempozyumlar, paneller, seminerler gerçekleştirilmekte, yeni yayınları okuyuculara tanıtıcı sergiler açılmakta, eğitici ve kültürel film ve slâytlar gösterilmekte, kü $\neg$ tüphane ve kitapla ilgili çeşitli söyleşiler ve yarışmalar düzenlenmektedir.(Kütüphaneler ve Yayımlar Genel Müdürlüğü, 2019).
\end{abstract}

"Kütüphane Haftası" kutlamaları ile ilgili Kütüphane Haftasını Kutlama Yönetmeliği, T.C. Resmi Gazete 17625, 6 Mart 1982 tarihinde hazırlanmış yönetmelik, kutlamaların ne şekilde organize edileceği, amacı, merkezde ve taşrada programların nasıl yapılabileceğine dair umumi hükümleri içermektedir. Yönetmeliğin ilgili maddelerinde kutlamaların genel mesulü ve organizatörü Kültür ve Turizm Bakanlığı'na bağlı Kütüphaneler ve Yayımlar Genel Müdürlüğü ile Türk Kütüphaneciler Derneği olarak ifade edilmektedir.

"Bu yönetmeliğin amacı, Anayasa doğrultusunda kültürel kalkınmayı demokratik yollarla gerçekleştirmeye katkıda bulunan kütüphaneleri vatandaşların yakından tanımalarını sağlayarak daha çok yararlanmalarını temin gayesiyle kutlanan ‘Kütüphane Haftası'nda yapılacak faaliyetleri belirlemektir.” (T.C. Resmi Gazete 17625, 6 Mart 1982).

Merkezde icra edilmesi beklenilen kutlama faaliyetleri muhtevasında, "kütüphane ve kütüphanecilik meselelerini ele alan konularda kongre, sempozyum vb. toplantılar düzenlemek" şeklindedir. Taşrada icra edilmesi beklenilen kutlama faaliyetleri muhtevasında ise,

“yeni yayınları tanıtıcı sergiler düzenlemek; bölgedeki okullarda öğrenim gören öğrencilerin sergileri ziyaretlerini sağlamak; mahalli gazeteler, TRT, belediye hoparlörü vb. yerel imkânlardan yararlanarak hafta 
ile ilgili duyurular yapmak; çevredeki ilgili kişi ve kurumlar ile işbirliği sağlayarak haftanın önemine işaret eden konferanslar vermek; kütüphane ve kitap okuma konularını içeren makaleler hazırlayarak mahalli gazetelerde yayımlanmasını sağlamak"

ifadeleri ile programın genel anlamda esas ve usulü tayin edilmiştir. Ancak; Yılmaz'a göre (2010) genel anlamda tertip edilegelen program ve etkinliklere katılımın arzu edilen istikamette olmamasının hatta açıkçası Kütüphane Haftası etkinliklerine katılımın az olmasının temel sebebi; "Kutlamalarda ele alınan konular, çoğunlukla, kutlamaların amacına hizmet etmeyen ve sadece toplantı konusunda çalışan meslektaşlar tarafından izlenen konular oldu." (Yılmaz, 2010, s. 136).

\section{Kütüphane Haftası Afişleri}

Afiş, genel anlamda; cemiyetin tüm yaşam alanlarında insanların görebilecekleri yerlere konumlandırılan ve böylece insanları bilgilendiren ve yönlendiren muhtelif şekil ve ebattaki tanıtım medyası olarak tanımlanabilir. (Akengin ve Mazlum, 2018, s. 1614). Lukas Cranach tarafindan 1545 senesinde hazırlanmış olan el ilanları tarihteki ilk afiş örnekleri olarak kabul edilmektedir.( Er, 2012, s. 115). Kültürel etkinlikleri tanıtmak gayesiyle hazırlanan, gerçekleştirilmekte olan ya da gerçekleştirilmesi planlanan tiyatro, konser, sinema, spor, festival, seminer, konferans v.b faaliyetleri topluma duyurarak ilgili kişileri bu tür organizasyonlara yönlendirmeyi amaçlayan afişler "kültürel afişler" olarak tanımlanabilmektedir. (Akengin ve Mazlum, 2018, s. 1616). Afişste anlatım dilini belirleyen en önemli husus "etki"dir. Afişlerde mesajın hedef kitle üzerinde tesirli olabilmesi için seçilecek görsel iletişim dili önem arz etmektedir. Seçilecek teknik unsurlar zamanın ruhunu yakalayabilmelidir. Tipografi, resimli (illüstratif) öğeler, fotoğraf gibi anlatımlar uygun biçimde çözümlenmelidir. Afişte hiyerarşi meselesi ise bir diğer dikkat edilmesi gereken husustur. Afişte yer alan başlık, alt başlık gibi metinler, tipografik öğeler, punto, vurgu, tezat vb. gibi unsurlar, hedef kitleye hangi mesajı hangi sırayla okuyacağına dair rehberlik yapmalı ve bu istikamette afiş doğru ve çarpıcı bir şekilde tasarlanmalıdır. (Asan, 2014, s. 5-6). Elbette afiş, içinde bulunduğu çağın ruhunu yansitır.

Afiş tasarımı hemen her döneme göre farklılık göstermiştir. Bunun nedeni dönemin tasarımcılarının yine dönemin sanat algısı ve insanların bakışı ile doğru orantılı olarak çalışmalar sergilemiş olmasıdır. Örneğin bir 'Casablanca' (1942) renk kombinasyonu, insan figürlerinin kullanımı olarak daha sicak tonlarda nostaljik retro bir hava ile tasarlanmıştır. Daha yakın örneklerden 'Matrix' (1999) ise dijital çağa uygun olarak ve filmin içeriğini yansıtarak yazılım kodlarına benzer şekiller ile afişleri süsler. Bilgisayar çağı ile filmin niteliğinde olan bilgisayar kültürü afişe yansıtılmıştır. Zamana uygun insan figürleri, kıyafetler ve takılar çağın gerekliliğine ve filmin içeriğine uygun olarak afişteki yerini almıştır. (Polat ve Kavuran, 2018, s. 66-67).

Araştırma konumuz açısından meseleyi inceleyecek olursak, genelde; halkla ilişkiler araçlarından yararlanma konusunda, özelde ise; "kütüphane haftası" afişlerinin icap eden tesiri uyandıramadığından müşteki olan Dr. Erol Yılmaz:

Her yıl hafta kutlamaları için bir afiş hazırlatılmakta, bu afişler kütüphaneler ve bilgi merkezlerine, Bilgi ve Belge Yönetimi bölümlerinin bulunduğu üniversitelerdeki farklı yerlere, toplu taşıma araçlarına ve kütüphanelerimizin bünyesinde yer aldıkları kurumların farklı yerlerine asılmaktadır. Bunun yapılmasındaki amaç, açıktır ki, toplumu Kütüphane Haftasından haberdar etmektir. Ancak bu noktada çok büyük bir eksiklik de aynı anda yapılmış olmaktadır. Şöyle ki, son derece önemli bir misyonu olan afişlerin üzerinde sadece haftanın adı, tema, kutlama tarihi, etkinliklerin yapıldığı mekânın adresi ve ana organizatör olan iki kurumun adı yer almaktadır. Belirtilen tarihler arasında hangi gün, hangi saatte, hangi etkinliğin 
gerçekleşeceği ve bu etkinliklerde kimlerin rol alacağına ilişkin olarak afişin üzerinde hiçbir bilgi yer almamaktadır. Bu nedenle de, kütüphaneler (ve ilgili unsurlar) konusunda farkındalık düzeyini artırmayı hedeflediğimiz toplumun içinden birileri mesleğimize, kütüphanelere ve verilen bilgi hizmetlerine ilgi duysa ve katılmak istese bile, bu bilgiler olmadan katılamayacağı için, afişin üstünü okuyup, geçip gitmektedir. Oysa program halkı hedefleyerek hazırlansa ve bu amaçla oluşturulan program içeriği (tamamen veya toplumsal albenisi bazında kısmen) afişin üzerinde uygun şekilde yer alsa, en azından daha fazla ilgi ve dikkat çekecek, bireyler katılmak isteyebileceği programları görerek katılım için daha fazla motive olacaktır. Bu konuda bugüne kadarki tek istisna, 42. Kütüphane Haftasında yapılan uygulamadır. O hafta, etkinlikler içerisinden konusu ve katılımcıları bağlamında toplumun daha çok ilgisini çekeceği düşünülen etkinlikler hazırlanan afişin bir köşesinde yer almıştı. İlginçtir, ne gibi bir zararı görüldüyse hemen ertesi yıl bu uygulamadan vazgeçildi. Bir daha da yapılmad1. (Yılmaz, 2010, s. 139).

\section{Göstergebilim ve Roland Barthes}

İnsanlık tarihiyle birlikte bugüne kadar geçen zaman diliminde insanlar, içinde yaşadıkları dönemin hususi özelliklerine göre ifade imkânları geliştirmişlerdir. Teknik ve teknolojik gelişmelere koşut, kültürler görselleşmiştir. Bu kültürel başkalaşım, içinde bulunduğumuz çağı daha ziyade imgeler ve görüntülerden teşekkül ettirmiştir. Bilgi ve iletişim çağı olarak kabul ettiğimiz çağımızda, bu imgelerin ve görüntülerin, en genel anlamda "göstergelerin" anlamlarını çözebilmenin önemi ortadadır. (Kalaman ve Bat, 2014, s. 129). Bu bakımdan "göstergebilim" günümüzde analiz yöntemleri içerisinde dikkatleri üzerinde giderek daha fazla toplamaya başlamıştır. Göstergebilim hemen her disipline tatbik edilebilirliği ile de kullanışlı bir teknik olarak kabul edilmektedir.

Göstergebilim yazılı ve görsel unsurların, belli kriterler göz önünde bulundurularak inceleme ve yorumlama sürecidir. $\mathrm{Bu}$ yorumlama sürecinde kültürel değişimler, sosyal yapı göz önünde bulundurulmaktadır. $\mathrm{Bu}$ bağlamda da göstergebilim dilsel ya da dilsel olmayan öğe ayrımı yapmaksızın hareket etmektedir. Göstergebilimsel analize tabi tutulan unsurlar verilmek istenen mesajları ortaya koyarken aynı zamanda görünenin arkasındaki anlamı ortaya koymaya da olanak tanımaktadır. Göstergebilim birincil anlamın dışında derin anlama ulaşmaya çalışır. Anlamın ne olduğundan çok nasıl inşa edildiği üzerinde durur. (Oruç ve Türkay, 2018, s. 313).

John Locke (1632-1704) bilimin üç temel kolundan biri olması gerektiğini iddia ettiği Göstergebilime sistematik olarak temas eden ilk düşünür olarak kabul edilmektedir ve ilk kez (doctrine of signs) "göstergeler doktrini”" kavramsallaştırmasını kullanarak kendinden sonraki pek çok düşünüre ilham kaynağı olmuştur. (Çeken ve Arslan, 2016, s. 509). 20.yy başlarında ise modern anlamda ilmi bir metot olarak resimlere, kitaplara, fotoğraflara, afişlere, mimari eserlere, muhtelif lisanlara, masallara, filmlere, romanlara, şiirlere, logo ve amblemlere, trafik işaretlerine ve hatta paralara varıncaya kadar "göstergebilimin" tatbik edilebileceğine dair görüşler ileriye sürülmeye başlanılmıştır. (Yılmaz ve Temizkan, 2013, s. 87).

Göstergebilim çözümlemesinde temel amaç, anlamı ve anlam oluşumunu incelemek olduğundan inceleme nesnesinin bütüncül ve tamamlanmış bir yapı olması beklenir. İncelenecek nesnenin bu bütünlük içinde alıcıya bir anlam sunduğu düşünüldüğünde bu anlamın oluşum amaçları ve araçları göstergebilim aracılığıyla belirlenebilir. Bu belirleme her türlü inceleme nesnesi için ayrıntılı, yüzeyden derine inen bir okuma süreciyle gerçekleşebilir. Göstergebilim, nesnesinin birbirine benzeyen veya benzemeyen özelliklerini ortaya koyarak, nesnesinin önceden oluşturulmuş yapısını betimledikten sonra, onu değişik bakış açılarıyla inceler, bakış açıları arasında bağıntılar kurar ve bunları belli bir dizge içinde sunar. Hiçbir bakış açısına öncelik ve ayrıcalık tanımaz. (Kıran, 2004, s. 51). 
Göstergebilim metodunu herhangi bir nesneye, olguya ya da alana uygularken ait olduğu milletin ve memleketin dâhil olduğu medeniyetin kültürel kodlarını, içtimai yapısını, ahlakını, dinini ve dilini hesaba katarak değerlendirmek gerekir. (Polat ve Kavuran, s. 68).

Göstergebilim alanında geliştirilen tüm anlamlandırma modelleri büyük ölçüde birbirine benzeyen bir yapıyı paylaşırlar. Bu modellerin her biri anlamlandırma çalışmalarına şu ya da bu biçimde katılabilecek üç öğeyi içerir. Bunlar, 1. Gösterge, 2. Göstergenin gönderme yaptığı şey, 3. Göstergenin Kullanıcıları'dır. $\mathrm{Bu}$ üç öğeden gösterge, kendisinden başka bir şeye gönderme yapan, duyularımızla kavrayabileceğimiz fiziksel bir şeydir ve varlığı, kullanıcıların onu bir gösterge olarak kabul etmelerine bağlıdır. (Yılmaz ve Temizkan, 2013, s. 89).

Göstergebilim alanında "anlam"; tüm göstergelerin birbiriyle olan ilişkisinden ve aralarındaki zıtlıktan kendine ait bağlamı içinde doğmaktadır. Bir resimde, afişte ya da fotoğraftaki nesneler ve göstergeler bir anlam oluşturmak için, ilgili görsel bildirinin genel anlamına bir katkı sağlamak için afişin, resmin ya da fotoğrafın içinde yer alır. Diğer bir deyişle farklı gösterge türleri kullanılmış olsa da resim, afiş ya da fotoğraf tüm unsurların bir araya gelerek bir bütün halinde belirli bir "anlam" meydana getirebildiği bir bildiri olarak değerlendirilmelidir. (Işık ve Eşitti, 2015, s. 667).

Roland Barthes'in göstergebilimsel analiz tekniği ise esasen dört temel ilke üzerinden tanımlanıp uygulanabilir. Bunlar; "biçimselleştirme", "yayıncılık", “çoğulluk" ve "işlemsellik" ilkeleri olup bunlar çözümleme yapılırken aşamalı olarak kullanılmaktadır. Birinci aşama olan "biçimselleştirme" ile yapıtın biçimini araştırmak, ikinci aşamada "yayıncılık" ilkesi ile metnin/görselin anlamını ve çağrışımını esas almak, üçüncü aşama olan "çoğulluk" ile metnin/görselin çağrıştırabileceği ihtimal dâhilindeki tüm anlamları değerlendirmek ve son aşamada ise "işlemsellik" ilkesi ile metnin/görselin değerlendirmesi yapılır. (Karaman, 2017, s. 31).

Barthes'a göre düzanlam ve yananlamdan oluşan anlamlandırmanın iki düzeyi bulunmaktadir.

\begin{abstract}
Düzanlam anlatım düzlemi ya da gösterenden oluşurken, yan anlam ise, içerik düzlemi ya da gösterileni ifade etmektedir. Düzanlam, bir göstergenin neyi temsil ettiği, yananlam ise göstergenin nasıl temsil ettiğidir. Düz anlam (Denotation) ve yan anlam (Konnotation) Barthes'ın kuramının temelini oluşturmaktadır. Kuramın amacı üst-dillerin analiz edilmesidir. Bundan dolayı Barthes'ın bir göstergenin düz anlamından öte yan anlamı üzerinde yoğunlaştığı söylenebilir. Bir üst-dil dil’in üstünde bir dil olarak temelleniyor. Buna en somut örnek sosyal bilimler alanında yapılan araştırmalarda nesnel bulguları değerlendirmelerin yanı sıra nesneler (Gegenstände) hakkındaki metinler için bir üst-dil'in kullanılmasıdır. Üstdil, kelimelerde kendini apaçık gösteren iktidar yapılarını (Machtstruktur) ayrıştırmaya yardımcı olmaktadır. Göstergebilimin görevinin de bu yapıları ayrıştırmak olduğunu belirten Barthes'a göre mit (Mythos) modern dünyanın üst-dilidir. Barthes popüler kültürün tüketim gereçlerindeki gizlenmiş anlamları çözümlemeye çalışmıştır. Mitler, günümüzde tekrar üretilen bilinenlerden faydalanmaktadır. Barthes'a göre burada kavram biliminin asıl görevi gizli kalmış anlam düzlemlerini okumaktır. (Er, 2012, s. 118).
\end{abstract}

Düzanlam bir göstergenin zahiri/görünen ya da diğer bir tabirle ortada olan yoruma ihtiyaç bırakmayan kısmıdır. Yananlam "üstdili” oluştururken yoruma ihtiyaç duyar. Yananlamda gösterge izleyicinin kültürel bilgisi içinde yorumlanarak ortaya çıkmaktadır. Yani, yananlam o dili kullanan topluluğun bireylerinin bilgi, deneyim ve düşünceleri içinde şekillenebilmektedir. Her gösterge mutlaka bir yananlam barındırmaktadır. Bu yananlam kültürden kültüre farklı şekilde yorumlanabilmektedir. (Çakı, 2018, s. 82). 


\section{Analizi \\ “Kütüphane Haftası” Afişlerinin Roland Barthes'in Göstergebilim Metodu Çerçevesinde}

\section{Araştırmanın Amacı:}

Araştırmanın en temel amacı "kütüphane haftası" duyuru/tanıtım afişlerinin semiyotik analiz yöntemi marifetiyle incelenerek afişlerde verilmek istenen mesajların çözümlenerek açı̆̆a çıkarılmasıdır.

\section{Araştırmanın Önemi:}

Göstergebilimsel analiz metoduyla yazılı ve görsel materyallerin hangi amaç/amaçlar için kullanıldığını tespit etmek mümkün olabilmektedir. Bu araştırma ile Kütüphane Haftası afişlerinin ne türden açık ve örtük mesajlar içerdiğini ortaya koyduktan sonra bu mesajların anlam katmanlarının aralanarak incelenmesi daha nitelikli çalışmalar yapılabilmesine katkı sağlayabilir.

\section{Araştırmanın Yöntemi:}

Bu makale kapsamında T.C Kültür ve Turizm Bakanlığı'na bağlı Kütüphaneler ve Yayımlar Genel Müdürlüğü web sayfasında yer alan Kütüphane Haftası tanıtım afişleri göstergebilim (semiyolojik) metodu ile incelenmiştir. Kütüphane Haftası kapsamında hazırlanılmış olan afişler makalenin ilgili kısmında daha evvel açıklanmaya gayret edilen Barthes'ın göstergebilimsel analiz yöntemi kullanılarak çözümlenmiştir.

\section{Araştırmanın Evreni ve Örneklem Seçimi:}

Kütüphaneler ve Yayımlar Genel Müdürlüğü web sayfasından araştırmanın amacı ve hacmi hesaba katılarak seçilen farklı senelere ait toplam afiş sayısı (7) yedidir. Araştırma kapsamında amaçlı örneklem tekniği kullanılmıştır.

Nitel araştırma süreci oldukça karışık bir veri çeşitliliğine sahiptir. Araştırmacılar bu denli farklılaşan veri setinden, araştırdıkları konu kapsamında olan verileri toplama amacındadırlar. Bu amaçlı yaklaşım nitel araştırmanın, amaçlı örneklem yaklaşımlarına yatkınlığını belirlemektedir. Nitel çalışmalarda araştırmacının, incelediği olguyu açıklamasında yardımcı olacak birey ve mekân ve durumları, çalışma için seçmesi amaçlı bir seçimdir. Çünkü amaçlı seçilen örneklem, çalışma probleminin ve çalışmanın merkezi, incelenen olgunun anlaşılmasına yönelik zengin bilgiler sunabilecek niteliktedir. (Baltacı, 2018, s. 265).

\section{Araştırmanın Kısıtları:}

Afişlerin tam sayım örnekleminin alınmayıp amaçlı örneklem seçimi ile bir kısmının incelenmesi temel sınırlılıktır. Afişlerin analizinde spesifik olarak göstergebilim metodunun uygulanmasına ilaveten afişlerin çözümlenmesinde pek çok göstergebilimci içinden yalnızca Barthes’in yönteminin kullanılışı en temel kisit olarak tespit edilebilir.

\section{Araştırmanın Soruları:}

Araştırmada şu sorulara özellikle cevap aranmaya çalışılacaktır:

"Kütüphane Haftası" çerçevesinde hazırlanmış olan örneklem grubu afişlerinde "düz anlam” ve "yan anlam" bakımından neler bulunmaktadır?

"Kütüphane Haftası" çerçevesinde hazırlanmış olan afişler, hangi metafor, metonim ve mit kavramları içerisinde sunulmuştur? 


\section{Bulgular ve Tartışma}

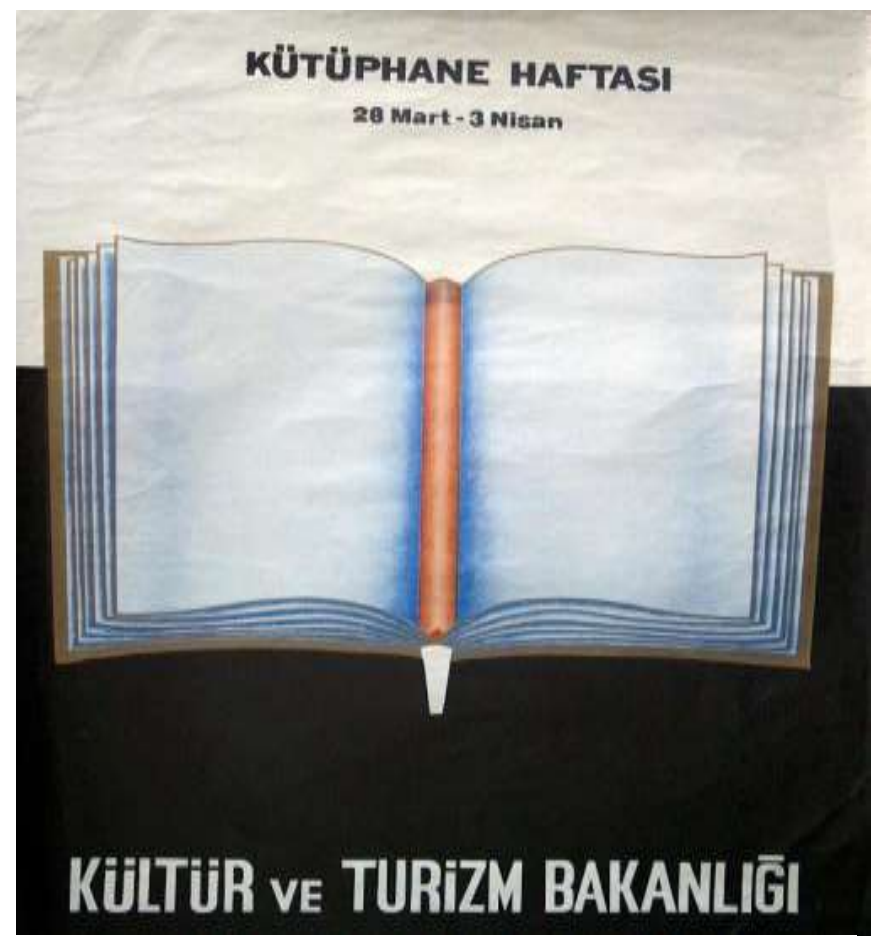

Afiş 1: Tarihsiz

$\mathrm{Bu}$ afiște tipografik olarak "Kültür ve Turizm Bakanlığl” ifadesi en alt kisımda vurgulanmıştır. Afiş düzanlam incelemesine tabi tutulduğunda; Afişin tam ortasında ortadan ikiye açılmış bir defter ve defteri aralayan bir kalem görsel kod olarak merkeze yerleştirilmiştir. Defterin her iki sayfası da boştur. Afişin üst kısmına sonradan damgalanmış "Kütüphane Haftasl" yazisı ve tarih olarak da sene belirtilmeksizin 28 Mart- 3 Nisan günleri derc edilmiştir. Afiş basit bir formda ve gayet sade tasarlanmıştır. Kütüphaneler ve Yayımlar Genel Müdürlüğü'nün ya da başka bir kurumun, derneğin, vakfin adı geçmemektedir. Afiş yananlam incelemesine tabi tutulduğunda; defter ve kalem "ilim" metaforu olarak kullanılmıştır. Afişte yer alan görsel kod unsurları kendi nesnel gerçekliklerini aşarak bilginin vasıtaları olarak metonimik öğeler olarak kullanılmışlardır. Bilginin mutlaka okuyup yazmakla elde edilebileceği miti üstdil olarak kurgulanmış ve afişin merkezine yerleştirilmişstir.

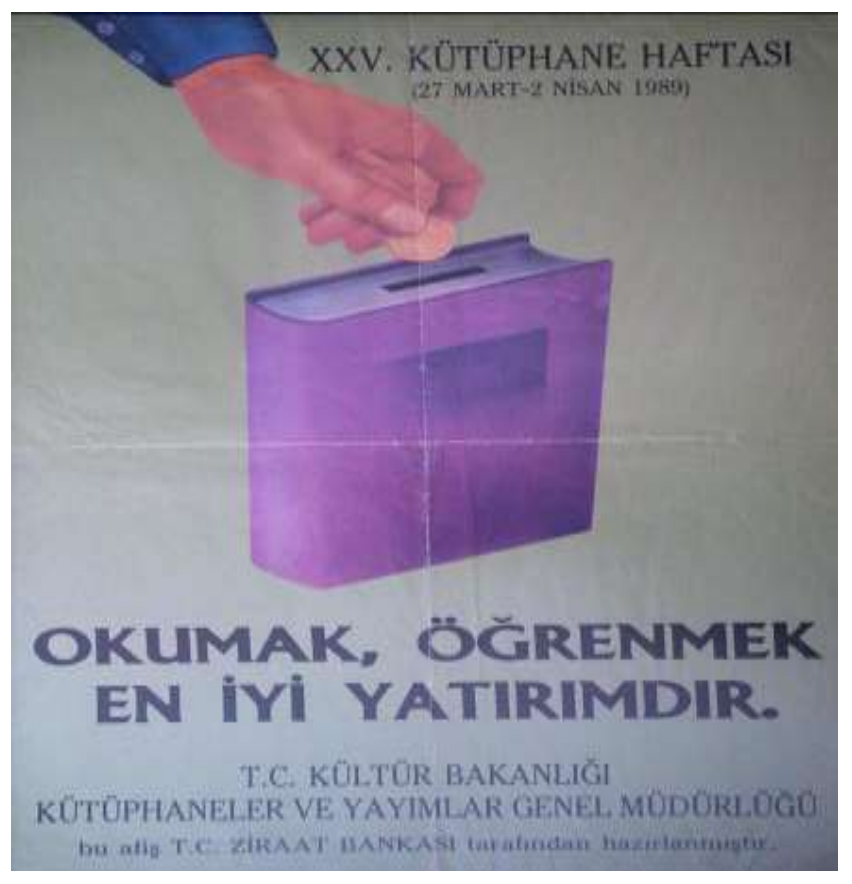

Afiş 2: 25. Kütüphane Haftası 1989
$\mathrm{Bu}$ afişte tipografik olarak üst kısmında "XXV. Kütüphane Haftasl (27 Mart-2 Nisan 1989)" açıklaması yapılmıştır. "Okumak, Ögrrenmek En İyi Yatırımdır” ifadesi görsel kodun hemen altına konumlandırılmıştır. Yine tipografik bakımdan "T.C Kültür Bakanlı̆̆ Kütüphaneler ve Yayımlar Genel Müdürlüğ̈̈" alt kisımda kurum/kuruluş olarak vurgulanmıştır. Afişsin en altında ise daha küçük punto ile "Bu afiş T.C Ziraat Bankası Tarafindan Hazırlanmıştır.” İfadesi yer almaktadır. Afiş düzanlam incelemesine tabi tutulduğunda; Afişin tam ortasında kitap şeklinde bir kumbara ve kitap kumbaraya para/altın atan bir el, görsel kod olarak merkeze yerleştirilmiştir. "Okumak, Öğrenmek En Iyi Yatırımdır" ifadesi görsel kod ile birlikte çözümlendiğinde "bilginin bir yatırım aracına" indirgendiği söylenebilir. Esasen 1989 senesi Kütüphane Haftası için 
afişi hazırlayan bir devlet bankasıdır. Afiş yananlam incelemesine tabi tutulduğunda; kitaptan kumbara "yatırım aracı" olarak gelecek için birikim yapılmak suretiyle "kazanç" metaforu olarak kullanılmıştır. Afiş̧e yer alan görsel kod unsurları kendi nesnel gerçekliklerini aşarak bilginin yatırım aracı olarak takdim edilmesinde metonimik öğeler olarak kullanılmışlardır. Bilginin birgün mutlaka maddi kazanca dönüştürülebileceği miti üstdil olarak kurgulanmış ve afişin merkezine yerleştirilmiş̧tir. Farklı bir perspektiften bakıldığında afiş̧e siyasetin etkisinin olup olmadığ meselesine dair yapılacak başka çalışmalara katkı sağlamak kastıyla; afişin tasarlandığı dönemin yani 1989 yılının Türkiye Cumhuriyeti Kültür Bakanı "Liberal ekonomik politikalarının mimarı" olarak bilinen Anavatan Partisindendir.

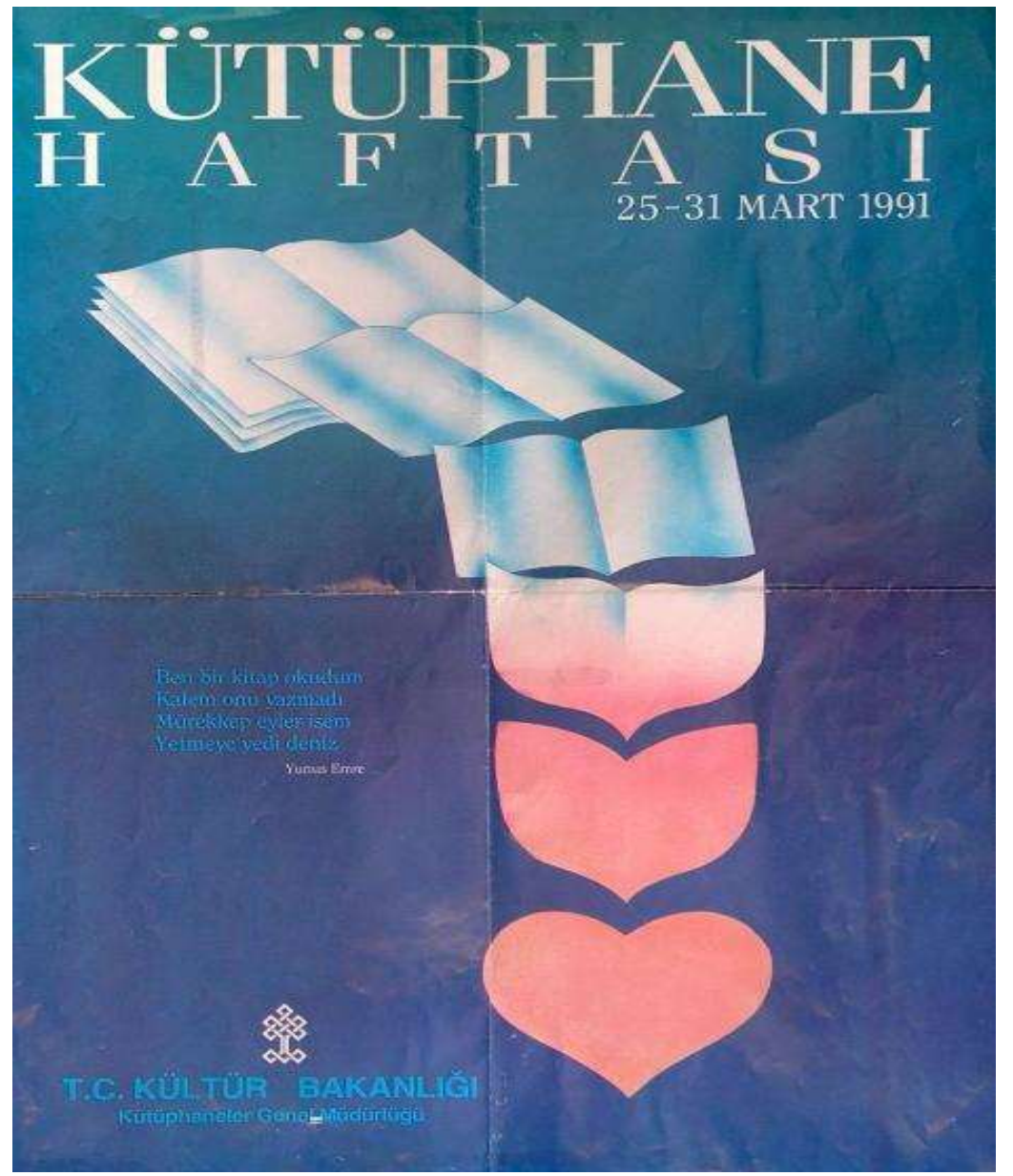

Afiş 3: Kütüphane Haftası 1991

$\mathrm{Bu}$ afişte de analize tipografik inceleme ile başlayacak olursak afişin üst kısmında "Kütüphane Haftasl (25 Mart-31 Mart 1991)" açıklaması yapılmıştır. Meşhur Türk mutasavvif Yunus Emre'nin "Ben bir kitap okudum, Kalem onu yazmadl, Mürekkep eyler isem, Yetmeye yedi deniz" dörtlüğü görsel kodun hemen yanına konumlandırılmıştır. Yine tipografik bakımdan "T.C Kültür Bakanliğl Kütüphaneler ve Yayımlar Genel Müdürlüğü" alt kısımda kurum/kuruluş olarak vurgulanmıştır. Afiş düzanlam incelemesine tabi tutulduğunda; Afişin tam ortasında görsel kod olarak kitap sayfaları kitaptan aşağıya doğru sanki bir şelale gibi akmakta ve kitap sayfaları nihayet en son "kalp" biçimine dönüşmektedir. Afiş̧ yananlam incelemesine tabi tutulduğunda; Meşhur Türk mutasavvıf Yunus Emre tarihsel sembolizm içerisinde tekabül ettiği anlam alanı görsel kod ile birlikte çözümlendiğinde "bilginin sevgiye" dönüşümünün nihayi bir amaç olması gerekliliğinin işaret edildiği söylenebilir. Esasen Yunus Emre "aşkın, sevginin, inancın" bir sembolüdür. kitaptan akan bilgi gönüle, kalbe giden "sevgi" metaforu olarak kullanılmıştır. Afişte yer alan görsel kod unsurları kendi nesnel gerçekliklerini aşarak bilginin sevgiye dönüştürülmesinde metonimik öğeler olarak kullanılmışlardır. Bilginin ancak maddi karşılıklarından arınarak, mana ciheti ile sevgiyi oluşturabileceği miti üstdil olarak kurgulanmış ve afişin merkezine yerleştirilmiştir. Farklı bir perspektiften bakıldığında afişte siyasetin etkisinin olup olmadığı meselesine dair yapılacak başka 
çalışmalara katkı sağlamak kastıyla; afişin tasarlandığı dönemin yani 1991 yılının Türkiye Cumhuriyeti Kültür Bakanı "Liberal ve kısmen muhafazakar kültür politikalarının mimarı" olarak bilinen Anavatan Partisindendir.

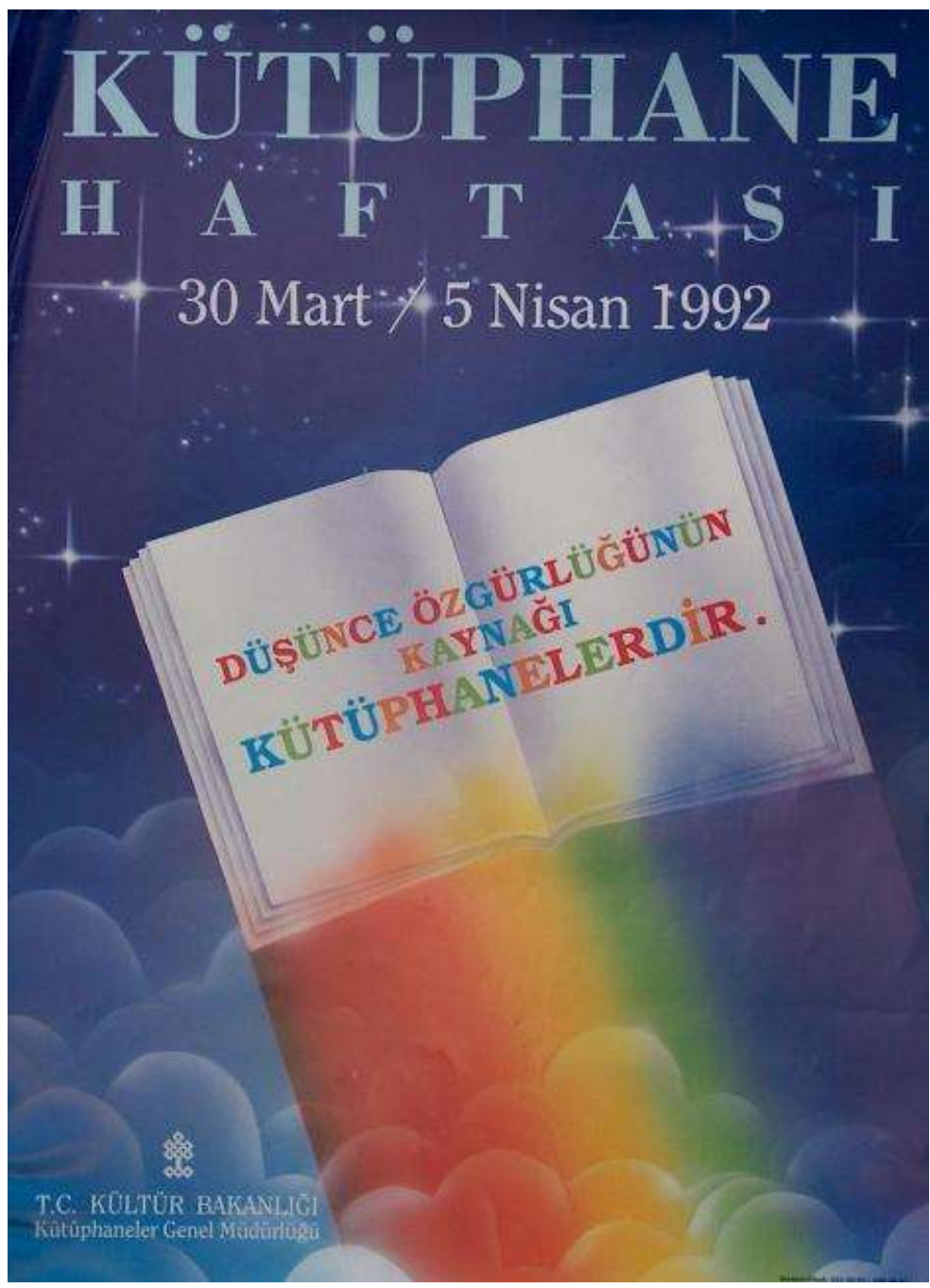

Afiş 4: Kütüphane Haftası 1992
$\mathrm{Bu}$ afişte tipografik bakımdan afişin üst kısmında "Kütüphane Haftast (30 Mart-5 Nisan 1992)" açıklaması yapılmıştır. "Düşünce Özgürlüğ̈̈nün Kütüphanelerdir." İfadesi slogan olarak görsel kodun içine konumlandırılmıştır. Yine tipografik bakımdan "T.C Kültür Bakanlığ Kütüphaneler ve Yaylmlar Genel Müdürlü̆̈̈̈" alt kisımda kurum/kuruluş olarak vurgulanmıştır. Afiş düzanlam incelemesine tabi tutulduğunda; Afişin tam ortasında görsel kod olarak arka plandaki uzay boşluğu ve uzaklarda parlayan yıldızlar dikkate alındığında; kitap sanki fezaya doğru yükselmekte olan bir füzeyi çağrıştırmaktadır. Afiş yananlam incelemesine tabi tutulduğunda; Kitap ve füze metaforu görsel kod ile birlikte çözümlendiğinde "bilginin" "gelişmeye ve ilerlemeye" işaret edebilmek için "füze" metaforu üzerinden tanımlandığı söylenebilir. Esasen füze ileri ve gelişmiş bilginin bir bakıma "uzay çağının" bir sembolüdür. Afiş̧te yer alan görsel kod unsurları kendi nesnel gerçekliklerini aşarak "Düşünce Özgürlüğ̈n̈̈n Kaynă̆ Kütüphanelerdir." İfadesi ile birlikte analiz edildiğinde ise; düşünce özgürlüğü ile uzay ve ilerleme vurgusu hesaba katılınca bilginin "ilericiliğe-gelişmişliğe" hamledilmesinde metonimik öğeler olarak kullanılmışlardır. Tam da bu noktada aşırı sayılamayacak bir yorumla "özgür düşüncenin" meydana getireceği bilgi birikiminin yani bilgi türü olarak ima edilen bilimsel bilginin "muasır medeniyetler seviyesine" ulaştıracak yegane araç olduğu miti üstdil olarak kurgulanmış ve afişin merkezine yerleştirilmiştir. Farklı bir perspektiften bakıldığında afişte siyasetin etkisinin olup olmadığı meselesine dair yapılacak başka çalışmalara katkı sağlamak 
kastıyla; afişin tasarlandığı dönemin yani 1992 yılının Türkiye Cumhuriyeti Kültür Bakanı "Sosyal demokrat politikaların temsilcisi” olarak bilinen SHP Partisindendir.

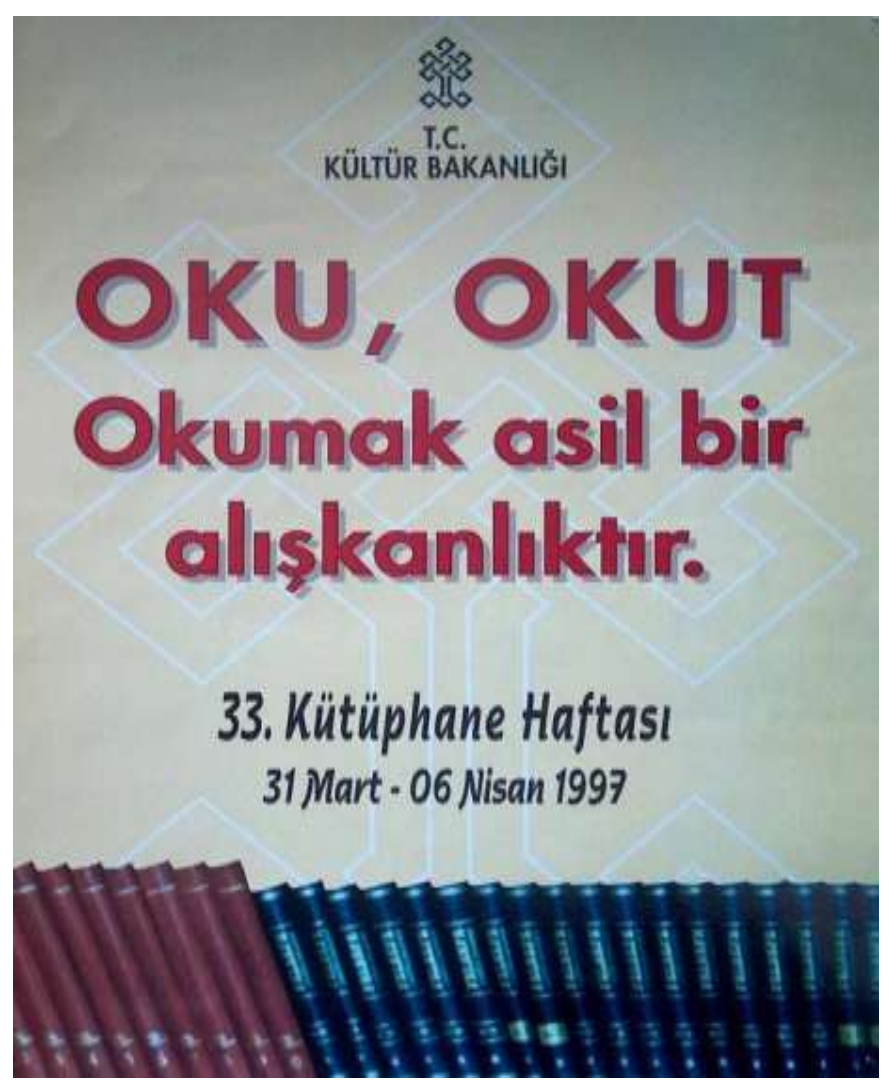

Afiş 5: Kütüphane Haftası 1997

Bu afişte tipografik bakımdan afişin üst kısmında "T.C Kültür Bakanlı̆̆l" haftayı tertip eden organizatör kurum/kuruluş olarak logosu ile birlikte vurgulanmıştır. Yine tipografik bakımdan alt kısımda "Kütüphane Haftası (31 Mart-6 Nisan 1997)” açıklaması yapılmıştır. "OKU, OKUT Okumak asil bir alışkanlıktır" ifadesi slogan olarak afişin merkezine konumlandırılmıştır. Görsel kod olarak sıra sıra dizilmiş iki farklı ansiklopedinin ciltleri bu afişte tipografik unsurların altında yer almıştır. Afiş düzanlam incelemesine tabi tutulduğunda; Afişin alt kısmında yer verilen görsel kod dikkate alındığında; iki farklı Ansiklopedinin ciltleri "bilginin sürekliliğine, bütünlüğüne" vurgu yapmakta ve okumanın bir alışkanlık olduğuna dair yapılan göndermeyi desteklemektedir. Afiş yananlam incelemesine tabi tutulduğunda; Kitap ciltleri yani ansiklopedi metaforu tipografik kod ile birlikte çözümlendiğinde "bilginin" "sürekliliği-bütünlüğü" özelliğine işaret edebilmek için "ansiklopedi" metaforu üzerinden anlatının tanımlandığ söylenebilir. Esasen ansiklopediler bilginin bir bakıma "alfabetik" dizaynı ile bu "sürekliliğe ve bütünlüğe" ait bir sembolüdür. Afişte yer alan görsel kod unsurları kendi nesnel gerçekliklerini aşarak “OKU, OKUT Okumak asil bir alışkanlıktır” İfadesi ile birlikte düşünüldüğünde ise; İslamın ilk emri olan "Oku” emrinin sloganik kullanımı dolayısıyla İslami bir söylem alanına yapılmış vurgu hesaba katılınca seküler bilginin "hakikat arayışına" inkılabında metonimik öğeler olarak kullanılmış olduğu fark edilecektir. İlginç olan ansiklopedi metaforunun seküler bilginin inşaa dönemi olan "Aydınlanma Çağı" na ait bir sembol oluşudur. İslamın "Oku”" emri ile Aydınlanmanın sloganı olan "sapere aud" yani "bilmeye cür'et et!" garip bir biçimde uzlaştırılmış ve bir oksimoron oluşmuş tam da bu sebepten her iki emir kipinde de ontolojik ve epistemolojik anlam buharlaşmıştır. Bilgiye ulaşmada ve bu bilginin elde edilebilmesinde araçsallaştırılan ansiklopedinin bilginin "sürekliliği-bütünlüğü” özelliğinin tesis ve temin edilebilmesinde tek yol olduğu miti üstdil olarak kurgulanmıştır. Farklı bir perspektiften bakıldığında afişte siyasetin etkisinin olup olmadığı meselesine dair yapılacak başka çalışmalara katkı sağlamak kastıyla; afişin tasarlandığı dönemin yani 1997 yılının Türkiye Cumhuriyeti Kültür Bakanı "Siyasal İslam politikalarının temsilcisi” olarak bilinen Refah Partisindendir. 


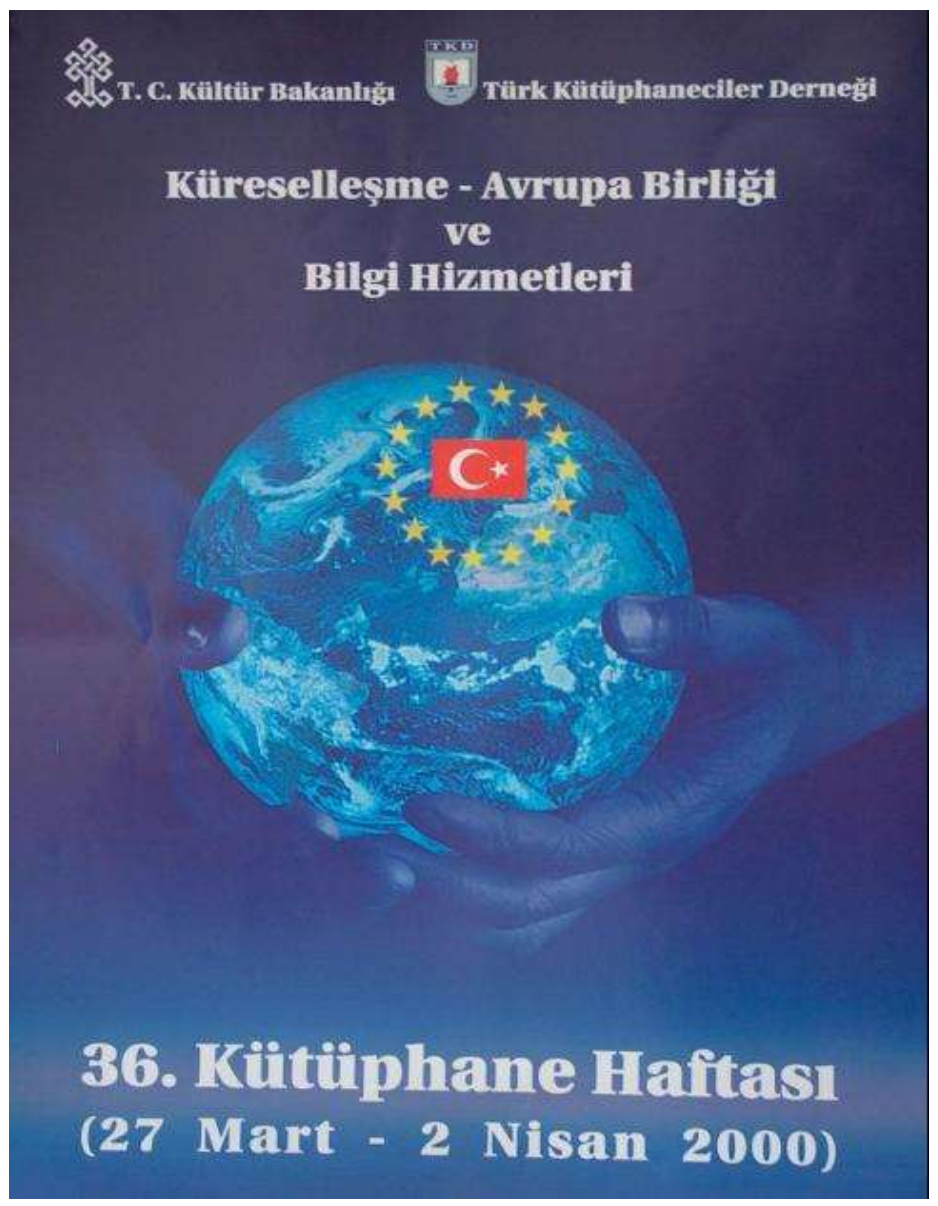

Afiş 6: Kütüphane Haftası 2000
$\mathrm{Bu}$ afişte tipografik bakımdan afişin üst kısmında "T.C Kültür Bakanlığg” ve "Türk Kütüphaneciler Derneği” haftayı tertip eden organizatör kurumlar/kuruluşlar olarak logoları ile birlikte vurgulanmışlardır. Yine tipografik bakımdan afişin en altında "36. Kütüphane Haftasl (27 Mart-2 Nisan 2000)" açıklaması yapılmıştır. "Küreselleşme-Avrupa Birliği ve Bilgi Hizmetleri" tematik ifadesi afişte görsel kod unsurlarının üstüne konumlandırılmıştır. Buradan hareketle; Kütüphane Haftası'nın temasının "Küreselleşme-Avrupa Birliği ve Bilgi Hizmetleri" olduğu belirtilmiştir. Görsel kod olarak "yerküreyi kavramış eller" afişin merkezindedir. Yerkürenin üzerinde ise Türk bayrağı ve etrafını kuşatmış Avrupa Birliği bayrağı yer almıştır. Afiş düzanlam incelemesine tabi tutulduğunda; Afişin merkezinde yer verilen görsel kod dikkate alındığında "yerküreyi kavramış eller" "bilginin küreselleşmesine, evrenselliğine" vurgu yapmakta ve "Küreselleşme-Avrupa Birliği ve Bilgi Hizmetleri" temasını desteklemektedir. Bu temanın tam da bu 2000 yılında seçilmesi de tesadüfi olmamıştır. 14 Nisan 1987 tarihinde Türkiye resmen tam üyelik başvurusunda bulunmuştur. Fakat bu isteği 18 y1l sonra kabul edilmiştir. Türkiye; Avrupa Birliği'yle bütünleşmenin ilk aşaması olarak 1 Ocak 1996 tarihinde Avrupa Birliği Gümrük Birliği'ne girmiştir. 2000'li yıllarda Türkiye'nin Avrupa Birliği'ne katılma sürecinde bir hızlanma gözlenmiştir. Afiş yananlam incelemesine tabi tutulduğunda; yerküre metaforu tipografik kod ile birlikte çözümlendiğinde "bilginin küreselleşmesi, evrenselliği” ve Bilgi merkezlerinin bu küreselleşme ve dolayısıyla evrenselleşme iddialarını ispat edebilmelerinin Avrupa Birliği'ne üye olmakla mümkün olabileceğine işaret edebilmek için "yerküre" ve "yerküre üzerinde etrafını Avrupa Birliği bayrağı kuşatmış Türk Bayrağı" metaforu üzerinden anlatının tasarlandığı söylenebilir. Esasen yerküre küreselleşme olgusunu temsil eden genel bir semboldür. Aynı şekilde afişte kullanılan hakim renk Avrupa Birliği bayrağındaki hakim renktir. Afişte yer alan görsel kod unsurları kendi nesnel gerçekliklerini aşarak "bilginin küreselleşmesi, evrenselliği" temasına uygun olarak metonimik öğeler olarak kullanılmıştır. Bilgi merkezlerinin küreselleşme ve evrensel olabilme meselesinde araçsallaştırılan Avrupa Birliği Üyeliğinin en etkili yol olduğu miti üstdil olarak kurgulanmıştır. 


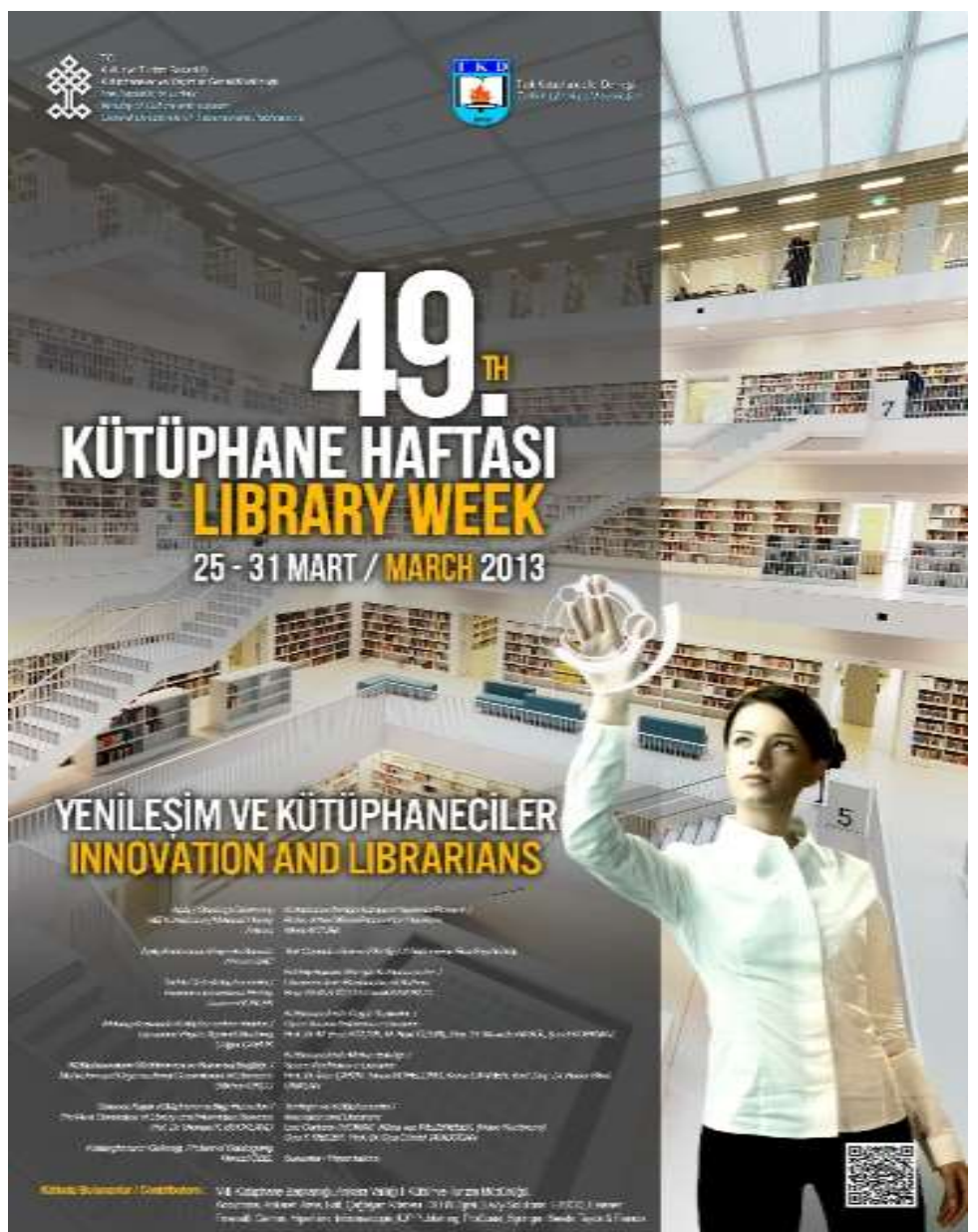

Afiş 7: Kütüphane Haftası 2013

$\mathrm{Bu}$ afişte tipografik bakımdan afişin üst kismında "T.C Kültür Bakanliğgl" ve "Türk Kütüphaneciler Derneği" haftayı tertip eden organizatör kurumlar/kuruluşlar olarak logoları ile birlikte vurgulanmışlardır. Yine tipografik bakımdan afişin hemen ortasında " 49 . Kütüphane Haftası (25 Mart-31 Mart 2013)" açıklaması yapılmıştır. "Yenileşim ve Kütüphaneciler tematik ifadesi afişte görsel kod unsurlarının üstüne konumlandırılmıştır. Buradan hareketle; Kütüphane Haftası'nın temasinın "Yenileşim ve Kütüphaneciler" olduğu belirtilmiştir. Diğer afişlerden farklı olmak üzere; tipografik unsurlardan biri 49. Kütüphane Haftası etkinlik programının afişin alt bölümünde yer alması ve diğer bir farklılık ise Türkçe ifadelerin İngilizce karşılıklarına da yer verilmesi olmuştur. Görsel kod olarak "ultra modern bir kütüphane" afişin merkezindedir. Kütüphaneci olduğu anlaşılan bir hanımefendi ise son teknoloji bir dokunmatik ekran üzerinde çalışma yapmaktadır. Afiş düzanlam incelemesine tabi tutulduğunda; Afişin merkezinde yer verilen görsel kod dikkate alındığında "ultra modern bir kütüphane" "yenileşime" vurgu yapmakta ve "Yenileşim ve Kütüphaneciler" temasını desteklemektedir. Afiş yananlam incelemesine tabi tutulduğunda; "ultra modern bir kütüphane" metaforu tipografik kod ile birlikte çözümlendiğinde "bilgi merkezlerinde inovasyona" ve Bilgi merkezlerinin bu yenileşim sürecinde iddialarını ispat edebilmelerinin son teknolojik donanıma sahip "ultra modern bir kütüphane"ye dönüşmekle mümkün olabileceğine işaret edebilmek için "ultra modern bir kütüphane" ve Kütüphaneci olduğu anlaşılan bir hanımefendinin son teknoloji ürünü bir dokunmatik ekran üzerinde çalışma metaforu üzerinden anlatının tasarlandığı söylenebilir. Esasen anlatıda "dokunmatik ekran" inovasyon olgusunu temsil eden bir semboldür. Afişte yer alan QR Kod uygulaması da "yenileşim" temasına uygun sembolik bir diğer unsurdur. Afişte yer alan görsel kod unsurları kendi nesnel gerçekliklerini aşarak "Yenileşim ve Kütüphaneciler" temasına uygun olarak metonimik öğeler olarak kullanılmıştır. Bilgi merkezlerinin ve kütüphanecilerin inovatif dönüşümlerini gerçekleştirebilme meselesinde araçsallaştırılan en son teknoloji ürünü ekipmanların "yenileşimi”" gerçekleştirebilmek için en etkili vasıtalar olduğu miti üstdil olarak kurgulanmıştır. 


\section{Sonuç}

Bu makale kapsamında T.C Kültür ve Turizm Bakanlı̆̆g'na bağlı Kütüphaneler ve Yayımlar Genel Müdürlügü web sayfasında yer alan Kütüphane Haftası tanıtım afisşleri göstergebilim (semiyolojik) metodu ile incelenmiştir. Kütüphane Haftası kapsamında hazırlanmış olan afiş̧ler Barthes'ın göstergebilimsel analiz yöntemi kullanılarak çözümlenmiştir. Araştırmanın en temel amacı "kütüphane haftası" duyuru/tanıtım afişlerinin semiyotik analiz yöntemi marifetiyle incelenerek afişlerde verilmek istenen mesajlar çözümlenerek açığa çıkarılmıştır. Kütüphaneler ve Yayımlar Genel Müdürlüğü web sayfasından seçilen toplam afiş sayısı (7) yedi olup araştırma kapsamında amaçlı örneklem tekniği kullanılmıştır. Yapılan analizler neticesinde afişlerde düz anlamın ötesinde yan anlam ve üst dil kurgulayabilmek için metaforik ve metonimik anlatıya müracaat edilmiştir. Afiş̧ler makro düzeyde tasarlandıkları dönemde dünyada sosyo-politik, sosyoekonomik, sosyo-kültürel gidişata koşut tasarlanmışlardır. Aynı meyanda afişler; mikro düzeyde de ülkemizdeki sosyo-politik, sosyo-ekonomik, sosyo-kültürel gidişata koşut tasarlanmışlardır. Göstergebilimsel analiz metoduyla yazılı ve görsel materyallerin hangi amaç/amaçlar için kullanıldığını tespit etmek mümkün olabilmektedir. Bu araştırma ile ülkemiz Kütüphane Haftası afişlerinin ne türden açık ve örtük mesajlar içerdiğini ortaya koyduktan sonra bu mesajların anlam katmanlarının aralanarak incelenmesi daha nitelikli çalışmalar yapılabilmesine katkı sağlayabilmesi hususu temel motivasyonumuzu oluşturmuştur.

\section{Kaynakça}

Akengin, G. ve Mazlum, H. (2018). Film Afişleri Örnekleri Üzerinden Tipografik Düzenlemelerin Görsel Alg1 Değerlerine Göre İncelenmesi, ulakbilge, 6 (30), 1613-1623.

Asan, H. (2014). Olimpiyat Oyunları Afişlerinin Göstergebilimsel Çözümlemesi:1896-2016 Yılları Arasındaki Afişler, Yayımlanmamış yüksek lisans tezi, Arel Üniversitesi, İstanbul

Baltacı, A. (2018). Nitel Araştırmalarda Örnekleme Yöntemleri ve Örnek Hacmi Sorunsalı Üzerine Kavramsal Bir İnceleme. BEÜ SBE Derg.,7(1), 231-274.

Çakı, C. (2018). Birinci Dünya Savaşı'ndaki Alman Propaganda Kartpostallarında Kullanılan Karikatürlerde Türklerin Sunumunun Göstergebilimsel Açıdan İncelenmesi. Akdeniz Üniversitesi İletişim Fakültesi Dergisi, (AKİL) Haziran (29) , 73-94.

Çeken, B. ve Arslan, A. A. (2016). İmgelerin Göstergebilimsel Çözümlenmesi “Film Afişsi Örneği”, Bayburt Eğitim Fakültesi Dergisi, Cilt: 11 Sayı: 2, 507-517.

Er, M. (2012). İhap Hulusi Görey'in Cumhuriyet Dönemi Afişlerinin Göstergebilimsel Açıdan incelenmesi, s.115 Türkbilig, /23: 115-132.

http://www.kygm.gov.tr/ , 02.03.2019 tarihinde Kütüphaneler Ve Yayımlar Genel Müdürlüğ̈̈/Kültür ve Turizm Bakanlığı adresinden erişildi.

Işık, M. ve Eşitti, Ş. (2015). I.Dünya Savaşı Propaganda Afişlerinde Kadın Temsillerinin Toplumsal Cinsiyet Bağlamında Göstergebilimsel İncelenmesi, Ankara Üniversitesi SBF Dergisi, Cilt 70, No. 3, $655-682$.

Kalaman, S. ve Bat, M. (2014). Toplumsal Cinsiyet Açısından Axe Basın ilanlarının Göstergebilimsel Analizi, KMÜ Sosyal ve Ekonomik Arastırmalar Dergisi 16 (Özel Sayı I): $128-136$. 
Karaman, E. (2017). Roland Barthes Ve Charles Sanders Peirce'1n Göstergebilimsel Yaklaşımlarının Karşılaştırılması, İstanbul Aydın Üniversitesi Dergisi 34,. 25-36.

Kıran, A. (2004). Göstergebilim ve Yazınsal Çözümlemeler, N. Tanyolaç Öztokat (Der). Disiplinler arası Ortam ve Yöntem Sorunları, 50-61., (İstanbul: Multilingual)

Oruç, M. C. ve Türkay, O. (2018). Türkiye Tanıtım Afişlerinin Göstergebilimsel Bir Analizi: Home Of Turkey Afişleri Örneği, The Turkish Online Journal of Design, Art and Communication TOJDAC, April Volume 8 Issue 2, 312-328.

Polat, B. Ve Kavuran, T. (2018). Emrah Yücel Sinema Film Afişlerinden New York’ta Beş Minare ve Kill Bill Film Afiş̧lerinin Göstergebilimsel Açıdan İncelenmesi, The Journal of Academic Social Science Studies, Number: 69, Summer II, 65-73.

Yılmaz, M. ve Temizkan, M. (2013). Türkiye Cumhuriyeti'nde Tedavüle Sürülen Banknotların Göstergebilimsel Çözümlemesi, Illetişim Kuram ve Araştırma Dergisi - Sayı 36 / Bahar,. 86131

Yılmaz, E. (2010). Kütüphane Haftası'nı Yeniden Düşünmek, Türk Kütüphaneciliği 24, 1 130-143. 